\title{
Gill metazoan parasites of the spotted goatfish Pseudupeneus maculatus (Ostheichthyes: Mullidae) from the Coast of Pernambuco, northeastern Brazil
}

\author{
L. Cardoso ${ }^{a}$, A. C. F. Lacerda ${ }^{*}$, E. L. T. Gonçalves ${ }^{a}$, D. I. Cadorin ${ }^{a}$, C. N. C. Bonfim ${ }^{c}$, \\ R. L. M. Oliveira ${ }^{c}$ and M. L. Martins ${ }^{a}$
}

\begin{abstract}
aLaboratório de Patologia e Sanidade de Organismos Aquáticos - AQUOS, Departamento de Aquicultura, Universidade Federal de Santa Catarina - UFSC, Rodovia Admar Gonzaga, 1346, CEP 88040-900, Florianópolis, SC, Brazil

'Programa de Pós-graduação em Ciências Biológicas - Zoologia, Laboratório de Hidrologia, Microbiologia e Parasitologia - LAHMP, Departamento de Sistemática e Ecologia, Centro de Ciências Exatas e da Natureza, Universidade Federal da Paraíba - UFPB, Campus I, Castelo Branco, CEP 58051-900, João Pessoa, PB, Brazil

'Departamento de Engenharia de Pesca e Aquicultura, Centro de Ciências Agrárias Aplicadas, Universidade Federal de Sergipe - UFSE, Rua Marechal Rondon, s/n, Jardim Rosa Elze, CEP 49100-000, São Cristóvão, SE, Brazil

*e-mail: acflacerda@dse.ufpb.br
\end{abstract}

Received: July 14, 2016 - Accepted: March 24, 2017 - Distributed: October 31, 2018

(With 1 figure)

\begin{abstract}
This study evaluated the parasite fauna on the gills of spotted goatfish Pseudupeneus maculatus captured in the dry and rainy seasons in the coast of the State of Pernambuco, Brazil. Eight parasite species were identified belonging to the following taxa: Monogenea (Haliotrema caraibensis, Haliotrema caballeroi and Haliotrema golvani); Crustacea (Rocinela signata, Hamaticolax scutigerulus and Caligidae gen. sp.) and Cestoda (Nybelinia indica and Pseudolacistorhynchus noodti). The most prevalent parasites were: Monogenea (100\%), H. scutigerulus (35\%), N. indica $(11.7 \%)$, R. signata $(8.3 \%)$, Caligidae gen. sp. (3.33\%) and P. noodti $(0.83 \%)$. Values of infestation are compared to other studies, and the uncommon occurrence of Trypanorhyncha on the gills suggests that the spotted goatfish could be an intermediate host for the parasite.
\end{abstract}

Keywords: marine fish, infestation, parasitology.

\section{Metazoários parasitos de brânquias do saramunete Pseudupeneus maculatus (Ostheichthyes: Mullidae) da costa de Pernambuco, Nordeste do Brasil}

\begin{abstract}
Resumo
O presente estudo investigou a fauna parasitária das brânquias do peixe conhecido como saramunete Pseudupeneus maculatus, capturados nas estações seca e chuvosa na costa do estado de Pernambuco, Brasil. Oito espécies de parasitos foram identificadas, pertencentes aos seguintes táxons: Monogenea (Haliotrema caraïbensis, Haliotrema caballeroi e Haliotrema golvani); Crustacea (Rocinela signata, Hamaticolax scutigerulus e Caligidae gen. sp.) e Cestoda (Nybelinia indica e Pseudolacistorhynchus noodti). Os parasitos mais prevalentes foram: Monogenea (100\%), H. scutigerulus ( $35 \%), N$. indica (11,7\%), R. signata (8,3\%), Caligidae gen. sp. (3,33\%) e P. noodti $(0,83 \%)$. Os valores de infestação são comparados a outros estudos, e a ocorrência incomum de cestóides Trypanorhyncha sugere que o saramunete pode ser um hospedeiro intermediário para o parasito.
\end{abstract}

Palavras-chave: peixes marinhos, infestação, parasitologia.

\section{Introduction}

The spotted goatfish Pseudupeneus maculatus (Bloch, 1793 ) is a marine demersal fish found in coral reefs, foraging mixed substrates of sand, gravel and rock (Krajewski et al., 2006; Sazima et al., 2006). It occurs in the West Atlantic, from Bermudas through New Jersey to the State of Santa Catarina, South Brazil (Hostim-Silva et al., 2006). It is common along the Brazilian littoral and extremely important for fishery in the State of Pernambuco (Santana et al., 2006; Lima et al., 2008).

The increase of fish consumption per capita and the development of farming practices around the world became accompanied by an increase in the studies involving parasites of marine fishes. Nonetheless, studies on the parasitic fauna associated with the spotted goatfish in 
Brazil are still scarce. Palm (1997) registered five species of Trypanorhyncha cestodes and Lima et al. (2008) reported the occurrence of nematode eggs of Capillaria sp., from fish captured in the State of Pernambuco, Brazil.

Parasite diversity and their ecological role in the ecosystems support tools for better understanding the biosphere (Luque and Poulin, 2007). In addition, the parasitological indexes allow us: to measure the amount of fish affected by the parasites in relation to the total population of analyzed fish; to know the extension of parasitic infestation; to comprehend the fish health status and; to detect natural and/or anthropogenic alterations (Barber et al., 2000; Nachev and Sures, 2009). This study investigated the metazoan parasites associated with the gills of wild spotted goatfish from the Coast of Pernambuco State, Northeast Brazil and the parasitological indexes along one year of sampling.

\section{Material and Methods}

Fish were captured from October 2012 to September 2013 from the Coast of Pernambuco, Brazil. The fish were captured by local fishermen at $20 \mathrm{~m}$ depth in the area comprising the following geographic locations: 1 ( $7^{\circ} 37^{\prime} 28.43^{\prime \prime} \mathrm{S} 34^{\circ} 1^{\prime} 10.24^{\prime \prime}$ ), close to Goiana municipality; 2 ( $\left.7^{\prime} 50.34^{\prime \prime} \mathrm{S} 34^{\circ} 43^{\prime} 41.73^{\prime \prime} \mathrm{O}\right)$ in the Metropolitan region of Recife; and 3 ( $\left.8^{\circ} 54^{\prime} 41.79^{\prime \prime S} 33^{\circ} 57^{\prime} 23.45^{\prime \prime} \mathrm{O}\right)$ close to São José da Coroa Grande municipality (Figure 1).
Fish were kept in thermal boxes with ice and transferred to the Marine Fish Farming Laboratory/LPM of Fisheries and Aquaculture Department/DEPAQ, Federal Rural University of Pernambuco/UFRPE for biometry and necropsy. The gills were processed according to Jerônimo et al. (2011), kept in flasks and sent to AQUOS-Aquatic Organisms Health Laboratory, Federal University of Santa Catarina for quantification and identification.

Monogenean parasites were mounted unstained in Hoyer's medium and identified according to Zhukov (1981) and Euzet and Vala (1976). The isopods were observed under a stereomicroscope and identified according to Brusca and France (1992). Taxonomic identification of copepods was based in adult specimens and processed following the Humes and Gooding (1964) method for identification (Vervoort, 1969; Ho and Lin, 2005; Morales-Serna and Gómez, 2010). Cestodes were stained with Langeron's alcoholic chlorhydric carmine, dehydrated and clarified in Beechwood creosote, mounted in Canada balsam (Eiras et al., 2006) and identified according to Palm $(1995,1997)$ and Palm and Walter (2000), Campbell and Beveridge (1994) and Chandra (1986). Parasitological indexes prevalence, mean intensity and mean abundance of parasites were calculated following Bush et al. (1997).

According to the pluviosity data provided by the Agência Pernambucana de Águas e Clima (APAC), the dry season was defined between October and March $(37.8 \pm 19.93 \mathrm{~mm})$, and the rainy season between April
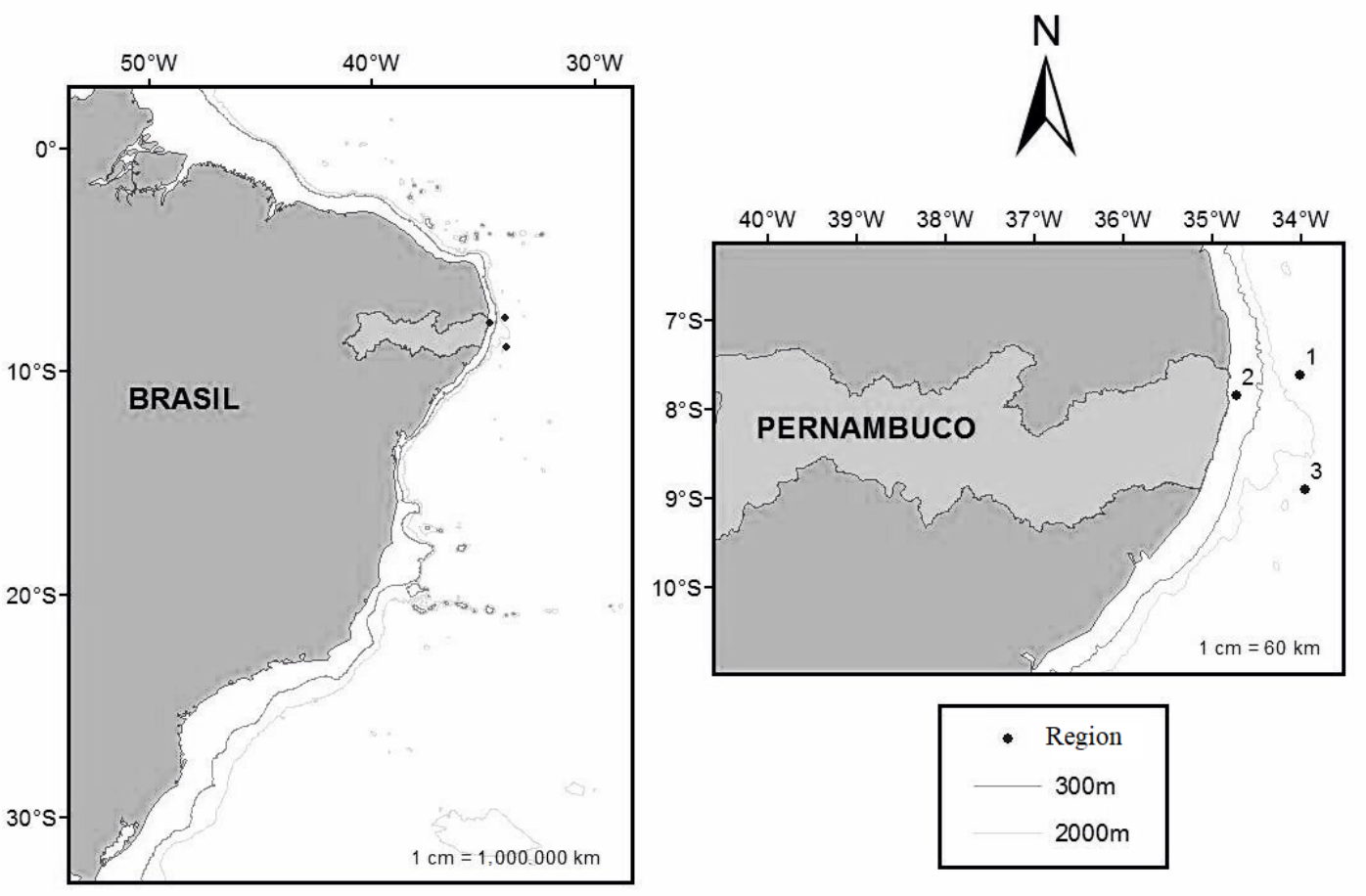

Figure 1. Location of the three sites (1,2 and 3) of capture of 120 specimens of Pseudupeneus maculatus used in this study. 
and September $(213.1 \pm 76.85 \mathrm{~mm})$. The abundance values of parasites were compared between seasons using the Mann-Whitney U test $(\alpha=0.05)$.

\section{Results}

A total of 120 specimens of $P$. maculatus (10 fish per month), with $140.2 \pm 45.2$ (47.5 to 262.1 ) $g$ and $21.5 \pm 2.1$ (16 to 27 ) $\mathrm{cm}$ total length were analyzed for parasites. Eight parasite taxa were collected, being the monogeneans Haliotrema caballeroi Euzet and Vala, 1976, H. golvani Euzet and Vala, 1976 and H. caraibensis Euzet and Vala, 1976 the most prevalent species, each of them presenting $100 \%$ prevalence. Haliotrema caballeroi also presented the highest values of mean intensity and mean abundance. The cestode Pseudolacistorhynchus noodti Palm, 1995 was the species with the lowest values of prevalence, mean intensity and mean abundance. Parasite taxa and respective values of prevalence, mean intensity and mean abundance are shown in Table 1.

The parasites that presented significant differences $(\mathrm{p}<0.05)$ between seasons were Haliotrema caraibensis (dry $440.7 \pm 681.2$; rainy $102.4 \pm 92.9$ ), H. caballeroi (dry $41.9 \pm 64.8$; rainy $10.2 \pm 9.0$ ) and $H$. golvani (dry $167.7 \pm 259.6$; rainy $38.2 \pm 35.9$ ), all of them presenting the highest abundance in the dry season.

\section{Discussion}

The knowledge of the parasitic fauna associated with marine fishes can contribute for better understanding the ecosystem complexity and ecological relationships. Different factors can have influence on the diversity and richness of fish parasites, such as sex, weight, length, eating habits, mode of life, geographic and seasonal distribution of the hosts in relation to time and space (Dogiel, 1964; Poulin and Morand, 2004).

Some interesting studies were performed regarding the parasitic fauna of marine fish. Cezar and Luque (1999) reported the metazoan parasites Monogenea, Digenea and Copepoda from Chaetodipterus faber in the Rio de Janeiro. Copepoda was the most abundant parasite and its prevalence was higher than the ones observed in the present study, possibly due to a monoxenic life cycle and eating habits including free-swimming stages of the parasites.

Studying the parasitic fauna of wild and farmed groupers Epinephelus marginatus in the Southeast Brazil, Roumbedakis et al. (2013) have also found different taxa composed by Monogenea Pseudorhabdosynochus beverleyburtonae (Oliver, 1984) Kritsky and Beverley-Burton, 1986, Neobenedenia melleni (MacCallum, 1927) Yamaguti, 1963 and Pseudempleurosoma sp. Yamaguti, 1965, Digenea Helicometrina nimia Linton, 1910 and larvae of Nematoda Contracaecum sp. Railliet \& Henry, 1912. Similar to that found in this study, they found $100 \%$ prevalence of P. beverleyburtonae. Luque et al. (2002) studied the metazoan community of parasites associated with Argentine goatfish Mullus argentinae captured in the littoral of the State of Rio de Janeiro, Brazil finding Digenea, Monogenea, Cestoda, Acanthocephala, Nematoda, Hirudinea and Isopoda. In terms of parasitological indexes, Luque et al. (2002) have reported lower values of Monogenea and Isopoda and higher values of Cestoda than that found in this study. In Argentina, Timi and Poulin (2003) studied the correlation between parasitic fauna (Monogenea, Digenea, Cestoda, Nematoda, Acanthocephala and Copepoda) and the length of the Argentine anchovy Engraulis anchoita. In contrast, in this study higher values of Monogenea, similar values of Copepoda and lower values of Cestoda were recorded.

The spotted goatfish is a marine fish living lonely or in small groups being commonly found in the bottom where moves the substrate searching for food mostly small invertebrates from the zoobenthos (Dubin, 1982; Aronson and Sanderson, 1987; Cervigón, 1993). This behavior associated with the monoxenic life cycle of monogenean parasites in which release eggs provided by filamentous structures (Whittington and Kearn, 1988; Grano-Maldonado et al., 2011), might have improved their transmission explaining the high prevalence rate $(100 \%)$ found in this study. The species of Haliotrema herein reported were also

Table 1. Prevalence (P), mean intensity (MI) and mean abundance of infestation (MA) \pm standard deviation (SD) followed by minimum and maximum values of gill metazoan parasites of Pseudupeneus maculatus from the Pernambuco Coast, Northeast Brazil

\begin{tabular}{lccc}
\hline \multicolumn{1}{c}{ Parasites } & P $(\mathbf{\%})$ & MI \pm SD (max-min) & MA \pm SD (max-min) \\
\hline Monogenea & 100 & $271.6 \pm 513.1(7-3523)$ & $271.6 \pm 513.1(7-3523)$ \\
Haliotrema caraibensis & 100 & $26.1 \pm 48.8(1-336)$ & $26.1 \pm 48.8(1-336)$ \\
Haliotrema caballeroi & 100 & $103.0 \pm 195.7(2-1341)$ & $103 \pm 195.7(2-1341)$ \\
Haliotrema golvani & & & \\
Cestoda & 11.7 & $1.3 \pm 0.5(0-2)$ & $0.1 \pm 0.4(0-2)$ \\
Nybelinia indica & 0.8 & $1.0(0-1)$ & $0.01 \pm 0.1(0-1)$ \\
Pseudolacistorhynchus noodti & & & $0.7 \pm 1.2(0-6)$ \\
Copepoda & 35 & $2.3 \pm 1.3(0-6)$ & $0.1 \pm 0.4(0-3)$ \\
$\begin{array}{l}\text { Hamaticolax scutigerulus } \\
\text { Caligidae gen. sp. }\end{array}$ & 3.3 & $2.0 \pm 0.8(0-3)$ & $0.1 \pm 0.3(0-2)$ \\
Isopoda & & & $1.1 \pm 0.3(0-2)$ \\
Rocinela signata & 8.3 & & \\
\hline
\end{tabular}


registered in spotted goatfish from the Guadalupe, Caribean Sea (Euzet and Vala 1976). Additionally, Zhukov (1981) observed H. longicornigerum Zhukov, 1981, H. pseudupenei Zhukov, 1981 and H. brevicornigerum Zhukov, 1981 in spotted goatfish from the Gulf of Mexico.

Isopods Aegidae from which Rocinela signata belongs are considered temporary or facultative parasites with low host specificity. They feed on the blood and generally are found associated with the gill chamber of marine fishes of economic importance (Bunkley-Williams et al., 2006; Hermida et al., 2014). This study showed similar values of infestation when compared to other fish species. Slightly higher prevalence in the spotted goatfish herein studied was observed in comparison to $M$. argentinae (Luque et al., 2002), lane snapper Lutjanus synagris (Cavalcanti et al., 2013), mutton snapper Lutjanus analis (Hermida et al., 2014), blue runner Caranx crysos, castin leatherjacket Oligoplites saliens and largehead hairtail Trichiurus lepturus (Carvalho-Souza et al., 2009), and the former have reported by the first time its occurrence in the Baía de Cotegipe, Bahia, Northeast Brazil. Contrarily to that observed in this study, high prevalence rates were found in Spanish mackerel Scomberomorus brasiliensis and in parrotfish Sparisoma frondosum from the Rio Grande do Norte (Lima et al., 2005; Cavalcanti et al., 2012). Bunkley-Williams et al. (2006) reported low prevalences of $R$. signata in tomtate grunt Haemulon aurolineatum $(0.45 \%)$, Corocoro grunt Orthopristis ruber $(0.49 \%)$ and in glasseye Heteropriacanthus cruentatus $(0.22 \%)$. In relation to mean intensity and abundance, similar values were found in M. argentinae (Luque et al., 2002), in L. synagris (Cavalcanti et al., 2013), in L. analis (Hermida et al., 2014), in C. crysos, O. saliens and T. lepturus (Carvalho-Souza et al., 2009) and in S. frondosum (Cavalcanti et al., 2012). Apart from the great variety of hosts for Aegidae its preference by some fish species must not be excluded once the prevalence values differ among different hosts.

The spotted goatfish P. maculatus from this study even showed to be parasitized by copepods. Caligidae has been reported parasitizing several marine fish species being found in high parasitic levels. As for example, in Brazil, Caligus bonito Wilson, 1905 was recorded in the mullet Mugil platanus (Knoff et al., 1994); Caligus praetextus Bere, 1936 in the common snook Centropomus undecimalis in the Rio de Janeiro, Southeast Brazil (Tavares and Luque, 2001); Tuxophorus caligodes, Caligus robustus Bassett-Smith, 1898, C. bonito, C. rufimaculatus Wilson, 1905 and Metacaligus rufus (Wilson, 1908) in the hosts O. saliens, $O$. palometa and O. saurus from Rio de Janeiro (Takemoto and Luque, 2002). Contrarily, the parasitological indexes previously found by those authors were greater than that related in this study. Apart from Caligidae gen. sp., another copepod was also found in spotted goatfish from Curaçao and Belize. The Bomolochidae Hamaticolax scutigerulus was described by Vervoort (1969) and Cressey (1983). In Brazil, Tavares and Luque (2003) have described new species of Bomolochidae Hamaticolax unisagittatus (Tavares \& Luque 2003) (=Acantholochus unisagittatus sp. nov.) in common snook from the Rio de Janeiro in high prevalence and mean abundance levels.

Copepods are small and abundant aquatic crustaceans found in many hosts from different microhabitats presenting the most important group associated with fish of economic importance. The ventral body structures and the hooks are one of the strategies used by the family Bomolochidae for attachment and sucking on the gills, internal portion of operculum, fins, skin and eyes of the hosts (Radhakrishnan and Nair, 1983; Boxshall et al., 2005). These parasites normally do not cause injury to the hosts unless present in very large quantities when the wounds are opened favoring the secondary infection.

Two species of Trypanorhyncha cestodes were observed encysted in the muscular region of the gills of spotted goatfish in this study: Nybelinia indica and Pseudolacistorhynchus noodti. Analyzing Trypanorhyncha from commercial fish of the Brazilian Coast, Palm (1997) observed Pseudolacistorhynchus noodti Palm, 1995, Mixonybelinia edwinlintoni (Dollfus, 1960) (=Nybelinia edwinlintoni), Pseudotobothrium dipsacum (Linton, 1897), N. indica e Nybelinia c.f. lingualis Cuvier, 1817 parasitizing the visceral cavity, mesentery and/or stomach wall of spotted goatfish in Pernambuco, Brazil. The prevalence found by Palm (1997) was higher for $P$. oodti, M. edwinlintoni, $P$. dipsacum and similar for $N$. indica e $N$. c.f. lingualis from the present study. These cestodes were also reported by Luque et al. (2002) in the visceral cavity of $M$. argentinae captured in the littoral of Rio de Janeiro; Silva Júnior (2010) in the muscle of South American silver croaker Plagioscion squamosissimus commercialized in the Fisheries Market, Amapá, Macapá, North Brazil; and by Dias et al. (2010), in the liver and mesentery of unicorn leatherjacket filefish Aluterus monoceros in the Rio de Janeiro, Southeast Brazil. Larval stages (plerocercoid) of these cestodes are mostly studied in intermediate hosts like teleost fishes, cephalopods and crustaceans. The adults of Trypanorhyncha can be found parasitizing the intestines of elasmobranchs, sharks and stingrays. According to the topic, the spotted goatfish $P$. maculatus can be considered another intermediate host for Trypanorhyncha cestodes.

In the present study, the abundance of monogeneans was higher in the dry season, which corresponds in great part to Spring and Summer. Some studies on monogenean parasites of marine fish also reported an increase in the number of parasites in the warmer seasons. Kamiso and Olson (1986) analyzed the fish Parophrys vetulus from the Coast of Oregon, USA, and observed the highest values of prevalence and mean intensity of the parasite Gyrodactylus stellatus (Olson and Pratt, 1973) in Spring. Bayoumi et al. (2008) analyzed five species of fish hosts from the Egyptian red sea, and found that Haliotrema sp. presented the highest values of prevalence during Spring and Summer. Rückert et al. (2010) studied several groups of parasites of Epinephelus fuscoguttatus in Indonesia and observed the highest prevalence of Benedenia epinepheli (Yamaguti, 1937) in the dry season. Luo and Yang (2012) analyzed the infestation of monogeneans on the gills of 
Epinephelus coioides from the South China Sea, and observed that the mean abundance of Pseudorhabdosynochus grouperi (Bu, Leong, Wong, Woo and Foo, 1999) was higher in Summer. Roumbedakis et al. (2013) observed that the abundance of Neobenedenia melleni (MacCallum, 1927) on the host Epinephelus marginatus from the Coast of Ubatuba, São Paulo State, Brazil increased during the warmer seasons.

It is known that mostly the water temperature, conditioned to pluviosity, has effect on the biology of hosts and parasites (Oliver, 1982; Soleng et al., 1999). It is the main abiotic factor responsible for regulating reproduction of monogeneans; in general, the embryonic period decrease with the increase of temperature and, for some species, there is a delay in the eggs eclosion under low temperatures (Gannicott and Tinsley, 1998). In addition, Bayoumi et al. (2008) state that the temperature affects the longevity of free-living stages, infectivity and life spam of monogeneans.

\section{Conclusion}

In conclusion, eight species of parasites belonging to three different taxa were found: Monogenea, Crustacea and Cestoda were recorded. All of Haliotrema species showed the highest parasitological indexes. The uncommon occurrence of Trypanorhyncha on the gills suggests that the spotted goatfish is an intermediate host for this parasite.

\section{Acknowledgements}

The authors thank the National Council of Scientific and Technological Development (CNPq) for Research grant to M.L. Martins (CNPq 305869/2014-0), to Dra Aimê R.M. Magalhães (Aquaculture Department, UFSC, SC, Brazil), Dra Gabriela T. Jerônimo (Post Graduate in Aquaculture, Nilton Lins University, AM, Brazil), Dr. Luis A.V. Arana (Aquaculture Department, UFSC, SC, Brazil) for critical review of the manuscript prior to submission.

\section{References}

ARONSON, R.B. and SANDERSON, S.L., 1987. Benefits of heterospecific foraging by the Caribbean wrasse, Halichoeres garnoti (Pisces: Labridae). Environmental Biology of Fishes, vol. 18, no. 4, pp. 303-306. http://dx.doi.org/10.1007/BF00004883.

BARBER, I., HOARE, D. and KRAUSE, J., 2000. Effects of parasites on fish behaviour: a review and evolutionary perspective. Reviews in Fish Biology and Fisheries, vol. 10, no. 2, pp. 131165. http://dx.doi.org/10.1023/A:1016658224470.

BAYOUMI, E.M., OSMAN, H.A.M., EL-BANA, L.F. and HASSANAIN, M.A., 2008. Monogenean parasites as bioindicators for heavy metals status in some Egyptian red sea fishes. Global Veterinaria, vol. 2, no. 3, pp. 117-122.

BOXSHALL, G.A., LESTER, R.D.G., GRYGIER, M.J., HOEG, J.T., GLENNER, H., SHIELDS, J.D. and LÜTZEN, J.,2005. Crustacean parasites. In: K. RODHE, ed. Marine parasitology. Collingwood: CSIRO Publishing, pp. 123-169.
BRUSCA, R.C. and FRANCE, S.C., 1992. The genus Rocinela (Crustacea: Isopoda: Aegidae) in the tropical eastern Pacific. Zoological Journal of the Linnean Society, vol. 106, no. 3, pp. 231-275. http://dx.doi.org/10.1111/j.1096-3642.1992.tb01248.x.

BUNKLEY-WILLIAMS, L., WILLIAMS JUNIOR, E.H. and BASHIRULLAH, A.K.M., 2006. Isopods (Isopoda: Aegidae, Cymothoidae, Gnathiidae) associated with Venezuelan marine fishes (Elasmobranchii, Actinopterygii). Revista de Biología Tropical, vol. 54, no. 3, pp. 175-188.

BUSH, A.O., LAFFERTY, K.D., LOTZ, J.M. and SHOSTAK, A.W., 1997. Parasitology meets ecology on its own terms: Margolis et al. revisited. The Journal of Parasitology, vol. 83, no. 4, pp. 575-583. PMid:9267395. http://dx.doi.org/10.2307/3284227.

CAMPBELL, R.A. and BEVERIDGE, I., 1994. Order Trypanorhyncha Diesing, 1863. In: L.F. KHALIL, A. JONES and R.A. BRAY, eds. Keys to the Cestode Parasite of Vertebrates. Wallingford: CAB International, pp. 51-148. chap. 7.

CARVALHO-SOUZA, G.F., SOUZA-NETO, J.R., ALELUIA, F.T., NASCIMENTO, I.A., BROWNE-RIBEIRO, H., SANTOS, R.C. and TINÔCO, M.S., 2009. Occurrence of isopods ectoparasites in marine fish on the Cotegipe Bay, north-eastern Brazil. Marine Biodiversity Records, vol. 2, pp. 1-4. http://dx.doi.org/10.1017/ S1755267209990844.

CAVALCANTI, E.T.S., NASCIMENTO, S.K.S., BARROS, N.H.C. and CHELLAPPA, S., 2012. Occurrence of the isopod parasite Rocinela signata (Isopoda: Aegidae) on marine fish Sparisoma frondosum (Osteichthyes: Scaridae). Journal of the Marine Biological Association of the United Kingdom, vol. 5, pp. 1-4. http://dx.doi.org/10.1017/S1755267212000516.

CAVALCANTI, E.T.S., NASCIMENTO, W.S., TAKEMOTO, R.M., ALVES, L.C. and CHELLAPPA, S., 2013. Ocorrência de crustáceos ectoparasitos no peixe ariacó, Lutjanus synagris (Linnaeus, 1758) nas águas costeiras do Rio Grande do Norte, Brasil. Biota Amazônia, vol. 3, no. 1, pp. 94-99. http://dx.doi. org/10.18561/2179-5746/biotaamazonia.v3n1p94-99.

CERVIGÓN, F., 1993. Los peces marinos de Venezuela. 2nd ed. Caracas: Fundación Científica Los Roques. 497 p.

CEZAR, A.D. and LUQUE, J.L., 1999. Metazoan Parasites of the Atlantic Spadefish Chaetodipterus faber (Teleostei: Ephippidae) from the Coastal Zone of the State of Rio de Janeiro, Brazil. Journal of the Helminthological Society of Washington, vol. 66, no. 1, pp. 14-20.

CHANDRA, K.J., 1986. Nybelinia indica n. sp. (Cestoda: Trypanorhyncha) from teleost fishes off Waltair coast, Bay of Bengal. Rivista di Parassitologia, vol. 47, no. 3, pp. 199-202.

CRESSEY, R.F., 1983. Parasitic Copepods from the Gulf of Mexico and Caribbean Sea, II: Bomolochidae. Washington DC: Smithsonian Institution Press. 35 p. Smithsonian Contributions to Zoology, no. 389, pp. 1-35. http://dx.doi.org/10.5479/si.00810282.389.

DIAS, F.J.E., CLEMENTE, S.C. and KNOFF, M., 2010. Larvae of Anisakidae nematodes and Trypanorhyncha cestodes of public health importance in Aluterus monoceros (Linnaeus, 1758) in Rio de Janeiro State, Brazil. Revista Brasileira de Parasitologia Veterinária, vol. 19, no. 2, pp. 94-97. PMid:20624345. http:// dx.doi.org/10.1590/S1984-29612010000200005.

DOGIEL, V.A., 1964. General parasitology. Edinburgh: Oliver and Boyd. 516 p. 
DUBIN, R.E., 1982. Behavioral interactions between Caribbean reef fish and eels (Muraenidae and Ophichthidae). Copeia, vol. 1, no. 1, pp. 229-232. http://dx.doi.org/10.2307/1444307.

EIRAS, J.C., TAKEMOTO, R.M. and PAVANELLI, G.C., 2006. Métodos de estudo e técnicas laboratoriais em parasitologia de peixes. 2nd ed. Maringá: EDUEM. 199 p.

EUZET, L. and VALA, J.C., 1976. Monogenean parasites of Mullidae (Teleostei) of the Guadeloupe coast. In: Excerta parasitologica em memoria del Doctor Eduardo Caballero y Caballero. Mexico: Universidade Nacional Autonoma de Mexico, pp. 45-44.

GANNICOTT, A.M. and TINSLEY, R.C., 1998. Environmental effects on transmission of Discocotyle sagittata (Monogenea): egg production and development. Parasitology, vol. 117, no. 5, pp. 499-504. PMid:9836315. http://dx.doi.org/10.1017/ S0031182098003205.

GRANO-MALDONADO, M., ROQUE, A., AGUIRRE, H. and FAJER-AVILA, E., 2011. Egg morphology, larval development and description of the oncomiracidium of Heterobothrium ecuadori (Monogenea: Diclidophoridae) parasitising the bullseye pufferfish, Sphoeroides annulatus. Helminthologia, vol. 48, no. 1, pp. 51-55. http://dx.doi.org/10.2478/s11687-011-0009-3.

HERMIDA, M., CARVALHO, B.F.L., CRUZ, C. and SARAIVA, A., 2014. Parasites of the Mutton Snapper Lutjanus analis (Perciformes: Lutjanidae) in Alagoas, Brazil. Revista Brasileira de Parasitologia Veterinária, vol. 23, no. 2, pp. 241-243. PMid:25054505. http://dx.doi.org/10.1590/S1984-29612014023.

HO, J. and LIN, C., 2005. A new bomolochid copepod parasitic on marine fishes of Taiwan, with reassignment of species of Holobomolochus Vervoort, 1969. Crustacean, vol. 78, no. 11, pp. 1369-1381. http://dx.doi.org/10.1163/156854005776759807.

HOSTIM-SILVA, M., ANDRADE, A.B., MACHADO, L.F., GERHARDINGER, L.C., DAROS, F.A., BARREIROS, J.P. and GODOY, F.,2006. Peixes de Costão Rochoso de Santa Catarina. I. Arvoredo. Florianópolis: Editora UNIVALI. 135 p.

HUMES, A.G. and GOODING, R.U., 1964. A method for studying the external anatomy of copepods. Crustaceana, vol. 6, no. 3, pp. 238-240. http://dx.doi.org/10.1163/156854064X00650.

JERÔNIMO, G.T., MARTINS, M.L., ISHIKAWA, M.M., VENTURA, A.S. and TAVARES-DIAS, M., 2011. Métodos para coleta de parasitos. Macapá: Embrapa, pp. 1-6. Circular Técnica, vol. 39.

KAMISO, H.N. and OLSON, R.E., 1986. Host-parasite relationship between Gyrodactylus stellatus (Monogenea: Gyrodactylidae) and Parophrys vetulus (Pleuronectidae) from coastal waters of Oregon. The Journal of Parasitology, vol. 72, no. 1, pp. 125-129. http://dx.doi.org/10.2307/3281804.

KNOFF, M., LUQUE, J.L. and TAKEMOTO, R.M., 1994. Parasitic copepods on Mugil platanus Günther (Osteichthyes: Mugilidae) from the coast of the State of Rio de Janeiro, Brazil. Revista Brasileira de Parasitologia Veterinária, vol. 3, no. 1, pp. 45-56.

KRAJEWSKI, J.P., BONALDO, R.M., SAZIMA, C. and SAZIMA, I., 2006. Foraging activity and behaviour of two goatfish species (Perciformes: Mullidae) at Fernando de Noronha Archipelago, tropical West Atlantic. Environmental Biology of Fishes, vol. 77, no. 1, pp. 1-8. http://dx.doi.org/10.1007/s10641-006-9046-z.

LIMA, J.T.A.X., CHELLAPPA, S. and THATCHER, V.E., 2005. Livoneca redmanni leach (Isopoda, Cymothoidae) and Rocinela signata Schioedte \& Meinert (Isopoda, Aegidae), ectoparasites of Scomberomorus brasiliensis Collette, Russo \& Zavala-Camin (Ostheichthyes, Scombridae) in Rio Grande do Norte, Brazil. Revista Brasileira de Zoologia, vol. 22, no. 4, pp. 1104-1108. http://dx.doi.org/10.1590/S0101-81752005000400041.

LIMA, M.M., TEIXEIRA, W.C., RAMOS, R.A.N., LIMA, A.M.A., ALVES, L.C. and FAUSTINO, M.A.G., 2008. Occurrence of eggs of Capillaria sp. in filet of fish saramunete (Pseudupeneus maculatus) marketed in the Metropolitan Area of Recife-PE/ Brazil. Medicina Veterinária, vol. 2, no. 1, pp. 35-37.

LUO, Y. and YANG, T., 2012. Seasonal patterns in the community of gill monogeneans on wild versus cultured orange-spotted grouper, Epinephelus coioides Hamilton, 1822 in Daya Bay, South China Sea. Aquaculture Research, vol. 43, no. 8, pp. 1232-1242. http:// dx.doi.org/10.1111/j.1365-2109.2011.02927.x.

LUQUE, J.L. and POULIN, R., 2007. Metazoan parasite species richness in Neotropical fishes: hotspots and the geography of biodiversity. Parasitology, vol. 134, no. 6, pp. 865-878. PMid:17291392. http://dx.doi.org/10.1017/S0031182007002272.

LUQUE, J.L., PORROZZI, F. and ALVES, D.R., 2002. Community ecology of the metazoan parasites of Argentine goatfish, Mullus argentinae (Osteichthyes: Mullidae), from the coastal of the state of Rio de Janeiro, Brazil. Revista Brasileira de Parasitologia Veterinária, vol. 11, no. 1, pp. 33-38.

MORALES-SERNA, F.N. and GÓMEZ, S., 2010. A new bomolochid copepod parasitic on bullseye puffer Sphoeroides annulatus (Jenyns) from Mexico, with reassignment of some species of Acantholochus Cressey and Hamaticolax Ho \& Lin. Zootaxa, vol. 2336, pp. 36-50.

NACHEV, M. and SURES, B., 2009. The endohelminth fauna of barbel (Barbus barbus) correlates with water quality of Danube River in Bulgaria. Parasitology, vol. 136, no. 5, pp. 545-552. PMid:19250599. http://dx.doi.org/10.1017/S003118200900571X.

OLIVER, G., 1982. Microcotyle chrysophrii Van Beneden et Hesse, 1863 (Monogenea, Polyopisthocotylea, Microcotylidae) parasite de Sparus aurata Linneaus, 1758 (Teleostei, Sparidae) dans les étangs littoraux du Languedoc-Roussillon (France). Parasitologie, vol. 20, no. 1, pp. 113-118.

PALM, H.W. and WALTER, T., 2000. Tentaculariid cestodes (Trypanorhyncha) from the Muséum national d'Histoire naturelle, Paris. Zoosystema, vol. 22, no. 4, pp. 641-666.

PALM, H.W., 1995. Untersuchungen zur systematik von rüsselbandwürmern (Cestoda: Trypanorhyncha) aus Atlantischen fischen. Berichte aus dem Institut für Meereskunde an der ChristianAlbrechts-Universität Kiel, no. 275, pp. 1-238.

PALM, H.W., 1997. Trypanorhynch cestodes of commercial fishes from Northeast Brazilian coastal waters. Memorias do Instituto Oswaldo Cruz, vol. 92, no. 1, pp. 69-79. PMid:9698918. http:// dx.doi.org/10.1590/S0074-02761997000100014.

POULIN, R. and MORAND, S., 2004. Parasite biodiversity. Washington: Smithsonian Institution Press. 216 p.

RADHAKRISHNAN, S. and NAIR, N.B., 1983. Nature of crustacean infestation of fishes along the South-West Coast of India I. Distribution, mode of attachment to the host tissue and incidence and intensity of infestation. Acta Ichthyologica et Piscatoria, vol. XIII, no. 2, pp. 93-115. http://dx.doi.org/10.3750/ AIP1983.13.2.06.

ROUMBEDAKIS, K., MARCHIORI, N.C., PASETO, A., GONÇALVES, E.L.T., LUQUE, J.L., CEPEDA, P.B., 
SANCHES, E.G. and MARTINS, M.L., 2013. Parasite fauna of wild and cultured dusky-grouper Epinephelus marginatus (Lowe, 1834) from Ubatuba, Southeastern Brazil. Revista Brasileira de Biologia $=$. Brazilian Journal of Biology $=$ Revista Brasileira de Biologia, vol. 73, no. 4, pp. 871-878. http://dx.doi.org/10.1590/ S1519-69842013000400025.

RÜCKERT, S., KLIMPEL, S. and PALM, H.W., 2010. Parasites of cultured and wild brown-marbled grouper Epinephelus fuscoguttatus (Forskål, 1755) in Lampung Bay, Indonesia. Aquaculture Research, vol. 41, no. 8, pp. 1158-1169. http://dx.doi. org/10.1111/j.1365-2109.2009.02403.x.

SANTANA, F.M., MORIZE, E. and LESSA, R., 2006. Age and growth of the spotted goatfish, Pseudupeneus maculatus (Bloch, 1793) in Brazil, validated through marginal increment and oxytetracycline dyes in the sagittae. Journal of Applied Ichthyology, vol. 22, no. 2, pp. 132-137. http://dx.doi.org/10.1111/j.14390426.2006.00724.x.

SAZIMA, C., KRAJEWSKI, J.P., BONALDO, R.M. and GUIMARÃES, P.R. Jr., 2006. The goatfish Pseudupeneus maculatus and its follower fishes at an oceanic island in the tropical West Atlantic. Journal of Fish Biology, vol. 69, no. 3, pp. 883-891. http://dx.doi.org/10.1111/j.1095-8649.2006.01166.x.

SILVA-JÚNIOR, A.C.S., 2010. Parasitism of cestodes from Trypanorhyncha order in the musculature of Plagioscion squamosissimus (Perciforme: Sciaenidae), commercialized in Macapá, AP/Brazil. Ciência Animal Brasileira, vol. 11, no. 3, pp. 737-742.

SOLENG, A., JANSEN, P.A. and BAKKE, T.A., 1999. Transmission of the monogeneans Gyrodactylus salaries. Folia Parasitologica, vol. 46, pp. 179-184.

TAKEMOTO, R.M. and LUQUE, J.L., 2002. Parasitic copepods on Oligoplites spp. (Osteichthyes, Carangidae) from the Brazilian coastal zone, with the redescription of Tuxophorus caligodes Wilson, 1908 (Siphonostomatoida, Tuxophoridae). Acta Scientiarum. Biological Sciences, vol. 24, no. 2, pp. 481-487.

TAVARES, L.E.R. and LUQUE, J.L., 2001. Aspectos quantitativos das infrapopulações de Caligus praetextus Bere, 1936 (Copepoda, Caligidae) parasitos do robalo Centropomus undecimalis (Bloch, 1792) (Osteichthyes, Centropomidae) no litoral do estado do Rio de Janeiro, Brasil. Revista Brasileira de Zoociências, vol. 3, no. 2, pp. 253-258.

TAVARES, L.E.R. and LUQUE, J.L., 2003. A New Species of Acantholochus (Copepoda: Bomolochidae) Parasitic on Centropomus undecimalis (Osteichthyes: Centropomidae) from the Coastal Zone of the State of Rio de Janeiro, Brazil. Memorias do Instituto Oswaldo Cruz, vol. 98, no. 2, pp. 241-245. PMid:12764441. http:// dx.doi.org/10.1590/S0074-02762003000200013.

TIMI, J. and POULIN, R., 2003. Parasite community structure within and across host populations of a marine pelagic fish: how repeatable is it? International Journal for Parasitology, vol. 33, no. 12, pp. 1353-1362. PMid:14527518. http://dx.doi.org/10.1016/ S0020-7519(03)00203-0.

VERVOORT, W., 1969. Caribbean Bomolochidae (Copepoda: Cyclopoida). Studies on the Fauna of Curaçao and other Caribbean Islands, vol. 28, no. 1, pp. 1-125.

WHITTINGTON, I.D. and KEARN, G.C., 1988. Rapid hatching of mechanically-disturbed eggs of the monogenean gill parasite Diclidophora luscae, with observations on sedimentation of egg bundles. International Journal for Parasitology, vol. 18, no. 6, pp. 847-852. http://dx.doi.org/10.1016/0020-7519(88)90127-0.

ZHUKOV, E.V., 1981. New species of monogeneans of the genus Haliotrema Johnston et Tiegs, 1922 from the gills of fish of the families Pomadasyidae and Mullidae from the Gulf of Mexico. Parazitologicheskij Sbornik, vol. 30, pp. 179-189. 